two investigations has recently been reported by S. Bundey, C. O. Carter, and J. F. Soothill. ${ }^{2}$ Similarly, tests for the raised fasting level of insulin in the plasma and the excessive response to a glucose load have been advocated as methods of detecting people bearing the gene. ${ }^{3}$ A survey of other abnormalities found on investigation of patients with dystrophia myotonica, including the decreased plasma levels of immunoglobulins, ${ }^{2}$ electrocardiographic abnormalities, ${ }^{4}$ skull radiographic changes, 5 and the decreased number of motor units in the extensor digitorum brevis muscle of the foot $^{6}$ might also be of value in its preclinical detection.

Unfortunately all these last changes may be found in some normal people without dystrophia myotonica or in patients with other conditions. Even electromyographic myotonia may be found in diseases other than dystrophia myotonica, and cataracts may not always be of the classical type. Careful judgement, based perhaps on the result of several of these investigations, is required before sound advice can be given.

Studies of genetic linkage may circumvent some of these difficulties. If there is an easily recognized gene with a locus on a chromosome very close to that of dystrophia myotonica, its segregation in a family will be the same as that of the gene for dystrophia myotonica provided there is no "crossing over" of genes. Thus if a child has the linked gene he will carry the gene for dystrophia myotonica. For this type of genetic investigation to have optimal value the two alleles of the linked gene should be present in approximately equal proportions in the population, it should be possible to detect the heterozygote for this linked gene, and the gene should be so close to that for dystrophia myotonica on the chromosome that the frequency of cross-over should be negligible. But even with these provisos only a proportion of families will be suitable for application of this method of genetic counselling. J. H. Renwick and colleagues ${ }^{7}$ have recently reported a reappraisal of the clinical value of the linkage between the gene for dystrophia myotonica and the secretor gene.

People can be divided into those who secrete the ABH blood group substances in their saliva and other body fluids and those who do not. This apparently inconsequential property is governed by a gene which has been shown to be closely linked to that for dystrophia myotonica. ${ }^{8}$ The frequency of cross-over is small. It has been suggested that heterozygotes for the secretor gene may also be recognized. ${ }^{7}$ Unfortunately the third requirement for a gene used in linkage is not met; the frequency of the alleles for the secretor gene in the population is not optimum. Nevertheless, in appropriate matings, the analysis allows prediction of the presence or absence of the gene for dystrophia myotonica with a $92 \%$ probability. ${ }^{9}$

P. Harper and colleagues ${ }^{10}$ showed that the secretor status of an embryo may be recognized at the ninth week of gestation by the detection of blood group substances in the amniotic fluid obtained at amniocentesis. Thus, as Renwick and colleagues ${ }^{7}$ have pointed out, it is possible in a small number of appropriate matings to advise that it is very likely that the child will bear the gene for dystrophia myotonica. In this instance an abortion may be performed with the knowledge that in a subsequent pregnancy similar tests may indicate a much smaller risk. Dystrophia myotonica thus comes within the ever-increasing list of diseases for which antenatal diagnosis by amniocentesis is possible and selected abortion may allow the parents to have a family of normal children. ${ }^{11}$
1 Mott, F. W., British Medical fournal, 1910, 2, 1013. Bundey, S., Carter, C. O., and Soothill, J. F., fournal of Neurology,

Walsh, J. C., Turtle, J. R., Miller, S., and McLeod, J. G., Brain, 1970, 93, 731.

4 Evans, W., British Heart fournal, 1944, 6, 41.

5 Di Chiro, G., and Caughey, J. E., Acta radiologica, 1960, 54, 22.

McComas, A. J., Fawcett, P. R. W., Campbell, M. J., and Sica, R. E. P., fournal of Neurology, Neurosurgery and Psychiatry, 1971, 34, 121.

Renwick, J. H., Bundey, S. E., Ferguson-Smith, M. A., and Izatt, M. M., fournal of Medical Genetics, 1971, 8, 407.

${ }^{8}$ Mohr, J., A Study of Linkage in Man. Copenhagen, Munksgaard, 1954.

Renwick, J. H., and Bolling, D. R., fournal of Medical Genetics, 1971, 8, 399.

${ }^{10}$ Harper, P., Bias, W. B., Hutchinson, J. R., and McKusick, V. A., Fournal of Medical Genetics, 1971, 8, 438.

Nadler, H. L., Birth Defects: original article series, 1971, 7, 5. New York, National Foundation-March of Dimes.

\section{Intelligence and Fertility}

Since Sir Francis Galton first drew attention to the problem, many people have been disturbed at the possibility that the transition from a population in balance as a result of high fertility and high childhood mortality to one in balance as a result of planned small families and low childhood mortality might lower the general population's average genetic fitness. In so far as the ability to plan family size requires intelligence, restraint, and foresight there might be loss of genetic endowment for these qualities, which are socially valuable in a much wider context than merely that of family planning. Certainly couples in the more socially prestigious -and usually better paid-occupations were the first to achieve the small family pattern.

The tendency for families to be largest where standards of education, hygiene, and income are below the national average has laid a heavy burden on the welfare services, but it has in large part been successfully shouldered. Demographers expected that the differential fertility would be a transient phenomenon and would tend to disappear as the practice of effective family planning spread through the community. The 1951 and even more the 1961 censuses of England and Wales and of Scotland showed just such a trend for differential fertility to lessen. The relationship between socio-economic class and mean completed family size was now U-shaped, with the highest fertility at the two ends of the scale. This trend has also been observed in the U.S.A. and Europe. The British censuses showed a similar relationship for education, average fertility being highest when the husband was a university graduate and the wife had continued at school at least to age 17 and also when both husband and wife had had only the compulsory minimum of schooling.

Another narrower aspect of the same problem is the relation between intelligence as measured by standard intelligence tests and fertility. The results of such tests are known to have strong predictive value for academic success, especially in the more difficult subjects and for later achievement. They are consistently more reliable in prediction than schoolmasters' opinions or achievement in conventional academic subjects. What they measure is clearly one important factor, among others less easily assessed, in determining upward social mobility, success in intellectually demanding occupations, and the capacity to learn two or three different technical skills in a working lifetime. Yet in the 1930s it was shown in Bath, ${ }^{1}$ Leicester, $^{2}$ and Yorkshire ${ }^{3}$ that there was a consistent negative correlation between children's I.Q. and the number of their brothers and sisters. 
This was disturbing when coupled with the finding that the larger part of the variance of intelligence-test scores in school children in countries such as Britain was due to genetic variation. Fear of a fall in the average genetic endowment for the development of intelligence was in part at least allayed when the 1932 survey of 11-year-olds in Scotland was repeated in $1947^{4}$ and, though confirming the negative correlation of I.Q. and family size, showed a small gain in I.Q. However, this gain was probably merely a reflection of the social improvements which had led to a more striking gain over the same period in mean height and weight of children. Further, it was realized that a study starting with children gave no information about members of the previous generation who had had no children. It was also realized that mere membership of a large family tended to depress the verbal component in the I.Q. score. What was needed was a study of cohorts of children tested at school age and then followed up until they had largely completed their families.

Two American studies 56 of this kind, each based on about a thousand children, showed small positive correlations between I.Q. and family size, the relatively large families of those with lower I.Q. being balanced by a relatively high proportion who did not marry or who were childless in marriage. Once again the correlation was U-shaped. The highest fertility was shown by the exceptionally intelligent with I.Q.s of 130 or more, who averaged about three children each, and the next highest by those of below average I.Q. in the range of 56-85 in one study and 85-100 in the other. Below 56-that is, among the mentally handicappedfertility was understandably low. In a more recent study from Harvard ${ }^{7}$ the rise of fertility at below-average intelligence was no longer found. A positive correlation of fertility and I.Q. is perhaps to be expected once all children are planned. Other things being equal, it is the more capable parents, provided they have achieved a happy and stable marriage and enjoyed rearing their first two children, who will feel able to go on to a third or fourth child.

Recently a new influence has been brought to bear on family size by the movement for "zero population growth" with its slogan, "Two is enough". Many people would agree on the need for Britain and the rest of Europe to achieve in the near future a mean family size at the replacement rate of $2 \cdot 1$.
But it is important that there should continue to be variation in the size of families. A uniformity of two-child units would virtually limit natural selection to that from death in utero, which would very probably be insufficient to balance genetic deterioration from recurrent mutation. Fortunately this is unlikely to happen; the incidence of failure to marry and voluntary or involuntary infertility is unlikely to fall much below a total of $20 \%$ of the population, and this will be balanced by couples who have largerthan-average families, who will tend to be those with the greatest gifts for parenthood. The choice of the number of children to have is one for individual couples to make; the doctor's role is in providing the means for them to avoid unplanned pregnancies.

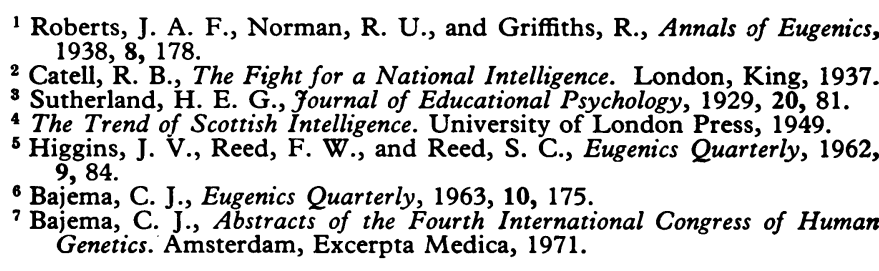

\section{Inverness Meeting}

The B.M.A. meeting to be held at the end of September at Inverness is the first of a new pattern. A provisional programme appears in the Supplement this week, and from this it will be seen that a variety of practical clinical topics have been selected for discussion. In successive years it is hoped to arrange a similar short programme at towns where a traditional longer meeting would be inappropriate owing to their relatively small size, geographical remoteness from teaching centres, or difficult communications. In fact Inverness (pop. 34,655) is larger than many places, has a good train service, and is remote only in the sense that it is 529 miles by road from the heart of the universe, London. But what it lacks in strict qualifications to be the guinea-pig for this experiment it makes up in the cordial welcome it promises all who attend. 